pedagogical authority of a teacher of higher education at the present stage of development]. Kharkov.

7. Starodubtsev, V. A. (2012). Sozdaniye personal'noy obrazovatel'noy sredy prepodavatelya vuza. [Creating a personal educational environment for a university teacher]. Tomsk.

\section{ВІДОМОСТІ ПРО АВТОРА}

РОЙТЕНКО Ніна Олексї̈вна - старший

викладач кафедри теорії музики та вокалу Південноукраїнського національного педагогічного університету імені К. Д. Ушинського.

Наукові інтереси: професійна підготовка майбутнього вчителя музичного мистецтва

\section{INFORMATION ABOUT THE AUTHOR}

ROYTENKO Nina Oleksiivna - Senior Lecturer of the Department of Music Theory and Vocal Theory of K. D. Ushinsky Southukrainian National Pedagogical University.

Circle of scientific interests: professional training of future music teachers.

Стаття надійшла до редакиії 15.02.2021 p.
UDC 881.378

DOI: $10.36550 / 2415-7988-2021-1-192-199-203$
SARNOVSKA Nataliia Ivanivna Lecturer, Foreign Languages Department Kyiv National University of Culture and Arts ORCID:https://orcid.org/0000-0001-7278-5183 e-mail: nat_sarnovskaya@ukr.net

ANTONIVSKA Maryna Oleksandrivna -

Lecturer, Foreign Languages Department Kyiv National University of Culture and Arts ORCID:https://orcid.org/0000-0002-4451-3735 e-mail: antonivska_maryna@ukr.net

\title{
ORGANIZING OF DISTANCE FOREIGN LANGUAGES TEACHING IN HIGHER EDUCATION ESTABLISHMENTS IN CURRENT CONDITIONS: PROBLEMS, METHODS, TECHNOLOGIES
}

Formulation and justification of the urgency of the problem. At the moment, due to the current situation in the country and in the world, the relevance of distance learning has become undeniable. This training format implies the process of interaction between the teacher and the student at a distance with the preservation of all components of training (goals, content, methods, organizational forms) and with the use of specific technical means (Internet technologies or other interactive environments). This article examines the forms and methods of distance learning and their integration into teaching a foreign language in higher educational establishments from the point of view of the advantages and disadvantages of their use in foreign language lessons.

Analysis of recent research and publications. Theoretical and practical aspects of distance learning have been considered in studies by both foreign and domestic scientists: J. E. Adams, F. Bodendorf, H. Dichanz, G. Hoppe, J. Kettunen, A. A. Andreeva, V. Yu. Vashchenko, K. R. Kolos, V. O. Kukleva.

There are many approaches and interpretations of the term «distance learning». For example, according to the Concept of
Distance Education Development in Ukraine of December 20, 2000, «distance learning is a set of technologies that deliver the main amount of material to 7 students, or any learners, and provide interactive interaction between students and teachers during the educational process, the method of providing students to work independently» [5]. According to V. Rybalko, distance education is important because it is a specific organization of the educational and pedagogical process, which is based on the use of distance, information and telecommunications technologies [7]. The author of the monograph «Theory and methods of informatization of education», I. V. Robert defines the term «distance learning» as a process of interactive interaction between student, teacher and interactive source of information resource, during which the transfer of knowledge, skills and abilities carried out in conditions of ICT implementation [9]. According to A. V. Khutorskyi, distance learning means learning, during which the participants in the process, i.e. the subjects of learning are at a distance and carry out the educational process by using the means of telecommunications [10].

The purpose of the article is to consider 
distance learning, analyze its advantages and shortcomings, explore ways of its implementation in the study of foreign languages at universities and to demonstrate the role of computer technologies and Internet resources in the development of foreign language communicative competence and the students' independent work skills forming. The research work was accompanied by the use of methods such as analysis of literary sources, comparative analysis, method of expert assessments. Full-time education is the most prestigious and high quality of all existing ones. It should also be noted that the majority chooses this particular form, since it is familiar and considered traditional. With the onset of 2020 , people realized the need and relevance of information technology and, in particular, distance learning. At the moment, everyone uses Internet resources to carry out their activities at a distance. This is a necessary measure that was established by the state of almost all countries in connection with the pandemic that began in February - March 2020. The main task is to limit contacts between people as much as possible. This led to a significant change in the education strategy, the most important feature of which is the widespread use of various information technologies. Since distance learning fully meets all the requirements of modern life and does not require supernatural skills and abilities, the population was able to quickly and clearly switch to it in the shortest possible time and without special training for both teachers and students.

The main material of the study. In the modern world, an indispensable component of successful mastering of a profession and promotion in the career ladder is knowledge of a foreign language, therefore, its study during university preparation seems appropriate and necessary. The goal of teaching a foreign language in higher educational establishments in the context of the implementation of a competence-based approach is to form students' communicative competence, which involves not only the development of speech skills and language skills, but also the assimilation of linguistic and cultural and socio-cultural knowledge. Full-time education is the most prestigious and high quality of all existing ones. It should also be noted that the majority chooses this particular form, since it is familiar and considered traditional.

You should pay attention to some points that have a significant impact on the implementation competence-based approach, which are associated with reducing the classroom load in the discipline «Foreign language». With the decrease in study time, the problem of increasing the effectiveness of teaching arose, the solution of which is being addressed by teachers of foreign languages. Naturally, this entailed analysis and revision of curricula and plans, and, as a result, the search for new approaches and techniques to optimize the learning process in new conditions [3]. Let us also add that the processes of integration and expansion of the world educational space require the development and implementation of new methods and technologies of vocational education in general and teaching a foreign language in particular. The grammar-translation method, which for many years was the basis of teaching foreign languages, has lost its relevance. The grammar-translation method, which for many years was the basis of teaching foreign languages, has lost its relevance. The need to introduce modern educational technologies into the educational process in order to improve the quality of education by intensifying the educational process and enhancing the independent work of students becomes obvious [8]. Students must learn to work well on their own and without constant guidance and monitoring by the teacher, making distance learning a challenge for those who are not easily motivated.

Distance education is understood as a special form of distance education, which includes classes conducted using Internet resources and audiovisual means. All distance learning methods are based on the independent acquisition of knowledge by students, at work with various sources of information. The effectiveness of this type of training requires the interconnection of many factors. These are, first of all:

- effective interaction between teacher and student, despite the physical separation by distance;

- the use of educational technologies;

- the effectiveness of training materials and methods of delivery;

- feedback efficiency.

With the onset of 2020, people realized the need and relevance of information technology and, in particular, distance learning. At the moment, everyone uses Internet resources to carry out their activities at a distance. This is a necessary measure that was established by the state of almost all countries in connection with the pandemic that began in February-March 2020. The main task is to limit contacts between people as much as possible. This led to a significant change in the education strategy, the most important feature of which is the widespread use of various information 
technologies. Since distance learning fully meets all the requirements of modern life and does not require supernatural skills and abilities, the population was able to quickly and clearly switch to it in the shortest possible time and without special training for both teachers and students.

Distance learning today provides a good opportunity to create systems of mass continuous self-learning, as well as the general exchange of information, regardless of the presence of time and space zones. If quite recently it was possible to integrate the distance form with the traditional full-time, then in this difficult situation it is necessary to completely reorganize to online education, which naturally caused a number of problems.

The specificity of teaching foreign languages reveals both general problems of distance learning, as well as characteristic only for the discipline «Foreign language». Distance learning allows you to implement individual study programs for students in the study of foreign languages. Often students with different levels of language proficiency come to the same group, especially if the foreign language was not specialized and was not an entrance test. Traditionally, the university is divided into subgroups depending on the level of language knowledge, for example, based on the results of the «placement test». However, the division into groups can be very uneven (equal-sized subgroups do not add up), even if the redistribution takes place within the entire current set, and not within one direction of training. Within the framework of distance learning, it is possible to create courses of several levels for implementation on one stream.

Distance learning is a new form in which the communication between the teacher and students takes place at a distance. This is one of the most modern forms of education, in which the educational needs of a student are met in a convenient mode for him, and competent educational programs are selected and developed [3]. Today, the educational system provides a large selection of forms and types of distance learning, such as various individual ecourses, video conferences, chat classes and other forms of organizing communication within the online process. The organization of distance learning is based on the traditional model, to which all students are adapted. They communicate with teachers, in the same way, follow their instructions and recommendations, answer the teacher's questions and can interact with their peers virtually.

In this situation, it is very important to be ready for this form of education, having the necessary equipment and an Internet connection. Since the teacher is a key figure in the educational process, it is important to organize, if possible, his personal interaction with students of middle and high school through Skype lessons or individual video consultations. It is important to periodically check the assimilation of the material covered and work on errors online. Teachers need to monitor student activity and change approaches and tools, removing the difficulties that students face.

A serious revision of the content of educational programs and individual lectures in universities is ripe. Not all lecturers need to be translated online or even left in the curriculum. Universities have a lot of traditional streaming lectures with an overall credit, which in fact represent a retelling of textbooks. It might be more effective to take advantage of specialized online courses from third-party universities or educational platforms. Released teachers can be loaded, for example, with methodological work. Alternatively, it is necessary to allocate an assistant for the teacher to record his online course - a young teacher or a master's assistant, who could make the content and form of the course more modern. In a traditional educational process, such a proposal would cause a lot of dissatisfaction, but now such cooperation will be perceived more favourably by both parties, and teachers will have their own high-quality online courses. Full-fledged distance learning is not limited to a simple recording of streaming lectures. It is very difficult to keep the attention of a student at home with a traditional lecture for an hour and a half. Streaming lectures online can be significantly shortened or given to students for listening for independent analysis along with reading books. The process of distance learning, retaining attention and engaging the listener in the cognitive process is much more difficult. Online training sessions should be divided into fragments in time, enter game modes, divide the listeners into several subgroups, where they could discuss the information received with the subsequent casting of the participants. There are a lot of features and practices in distance learning, and university leaders now need to make sure that teachers are familiar with them.

The systems for recording and evaluating the knowledge gained by students need to be revised. Everyone understands that at home, the student who takes the tests has access to all the electronic resources and experience of family members. For a qualitative assessment of the student's knowledge, it will be necessary to reformulate the test problems in the form of an essay or reflection, and in natural sciences, when checking tasks, focus not on the final digital 
answer, but on a detailed check of the logic of solving the problem. Knowledge testing can also be carried out in online debates between students themselves, where an experienced teacher as a listener will assess the depth of understanding of the topic by any of the discussants. If, after all, tests and traditional tasks are indispensable, it makes sense to introduce proctoring systems. These are widely used in foreign universities for the admission of foreign students.

You need to study the various Learning Management Systems (LMS). Distance learning, like any distance business process, requires new management systems. Previously, such systems were implemented at will, but now they are vital. Moodle is the most popular foreign platform in universities; developing your own LMS systems is a long and laborious process. Perhaps you should start by using existing platforms and then develop and implement your systems based on the experience gained.

In distance learning, feedback forms from students are especially important. This is not just a questionnaire for making instant disciplinary decisions. Students should not rate the course and the teacher on the «like it or not like it» principle. They should evaluate the complexity of the course, the form of presentation, the progress of their knowledge, the time spent. It is necessary to develop and implement various forms of feedback, often anonymous, in order to conduct long-term data analysis and improve the educational process.

Conclusions and prospects for further researches of directions. As you know, the study of distance learning has long attracted the attention of both theoretical methodologists and practising teachers. However, face-to-face and remote forms for a long time existed in parallel with the explicit priority of the first. The situation that has developed in connection with the introduced self-isolation regime has pushed for the rapid entry into the educational process of distance learning. Thanks to technological progress, full-time and distance learning were able to integrate, complementing, and in some cases replacing each other. Thanks to the competence of teachers in this area, integration has become possible and does not harm the educational process, but, on the contrary, improves and effectively complements it. Distance learning is based on modern information and communication technologies of training and advanced training. Distance learning technologies can be seen as a natural stage in the evolution of the traditional education system from the chalkboard to e-board and computer learning systems, from book library to e-mail, from the regular audience to the virtual audience. This process requires constant monitoring, study and searching for new tools and methods. Only by applying a combination of pedagogical knowledge and modern technologies it is possible to implement a successful foreign language distance learning.

\section{СПИСОК ДЖЕРЕЛ}

1. Андреев А. А. Дидактические основы дистанционного обучения в высших учебных заведениях: дис. ... доктора пед. наук: $13.00 .02-$ теория и методика обучения (создание и использование средств обучения) / А. А. Андреев [Электронный ресурс]-URL:

https://www.dissercat.com/content/didakticheskieosnovy-distantsionnogoobucheniya-v-vysshikhuchebnykh-zavedeniyakh

2. Ващенко В. Ю. Аналіз систем керування навчанням i контентом та їх впровадження в навчальний процес / В. Ю. Ващенко, О.В.Дядичев // Вісник ЛНУ імені Тараса Шевченка. 2011. No 12 (223), Ч. II. C. 5-17.

3. Гозман Л. Я. Дистанционное обучение на пороге XXI века / Гозман Л. Я., Шестопал Е. Б. Ростов-на-Дону, «Мысль», 1999. 368 с.

4. Колос К. Р. Система Moodle як засіб розвитку предметних компетентностей учителів інформатики в умовах дистанційної післядипломної освіти: дис. ...канд. пед. наук: 13.00.10 інформаційно-комунікаційні технології в освіті / К. Р. Колос // Житомирський державний університет імені Івана Франка. Житомир, 2011. $238 \mathrm{c}$.

5. Концепція розвитку дистанційної освіти в Україні: Постанова від 20 грудня 2000 / Міністерство освіти i науки України [Електронний ресурс] URL: http://www.osvita.org.ua/distance/pravo/00.html.

6. Куклев В. А. Становление системы мобильного обучения в открытом дистанционном образовании: автореф. дис. ... д-ра пед. наук: 13.00.01общая педагогика, история педагогики и образования / В. А. Куклев // Ульяновский государственный технический университет. Ульяновск, 2010. $46 \mathrm{c}$.

7. Кухаренко В. М., Рибалко О. В., Сиротенко Н. Г. Дистанційне навчання: умови застосування. Дистанційний курс: навч. пос. / В.М. Кухаренко, О. В. Рибалко, Н. Г. Сиротенко // Х: НТУ «ХПІ», «Торсінг», 2002. 320 с.

8. Полат Е. С. Организация дистанционного обучения иностранному языку на базе компьютерных телекоммуникаций [Электронный pecypc]. URL: http://www.ejoe.ru/sod/98/1_98/st007.html

9. Роберт И. В. Теория и методика информатизации образования (психологопедагогический и технологический аспекты), 2014. 398 с. [Электронный ресурс] URL:https://docplayer.ru/30279183-Teoriya-imetodikainformatizacii-obrazovaniya.html

10. Хуторской А. В. Практикум по дидактике и современным методикам обучения / А. В. Хуторской // СПб.: Питер, 2004. 541 с. 


\section{REFERENCES}

1. Andreev, A. A. Didakticheskiye osnovy distancionnogo obycheniya $v$ vysshih uchebnyh zavedeniyah. [Didactic foundations of distance learning in higher educational establishments].

2. Vashchenko, V. Yu. (2011). Analiz system keruvannia navchanniam $i$ kontentom ta yii vprovadzhennia $v$ navchalnyi process. [Analysis of learning and content management systems and their implementation in the educational process]. Lviv.

3. Gozman, L. Ya. (1999). Distantsiohhoye obuchenie na poroge XXI veka. [Distance learning on the threshold of the $21^{\text {st }}$ century]. Rostov-na-Donu.

4. Kolos, K. R. (2011). Moodle yak zasib rozvytku predmetnyh kompetentnostei uchetyliv informatyky $v$ umovah dystantsiynoi pisliadyplomnoi osvity. [Moodle system as a means of developing subject competencies of computer science teachers in terms of distance postgraduate education]. Zhytomyr.

5. Kontsepciia pozvytku dystantciynoyi osvity $v$ Ukraini. [The concept of development of distance education in Ukraine].

6. Kuklev, V. A. (2010). Stanovleniye sistemy mobilnogo obycheniya $v$ otkrytom distantsyonnom obraxovanii. [Formation of the mobile learning system in the open distance education]. Ulyanovsk.

7. Kukharenko, V. M, Rybalko, O. V., Sirotenko, N. G. (2002). Distantsiyne navchannia umovy zastosuvannia. [Distance learning: terms of use.]

8. Polat, E. S. Organizatsiya disrantsionnogo obucheniya inostrannomu yazyku na baze kompyuternyh telekommunikatsyy. [Organization of distance learning in a foreign language based on computer telecommunications].

9. Robert, I. V. (2014). Teoriya I metodika informatizatsii obrazovaniya. [Theory and methodology of informatization of education (psychological, pedagogical and technological aspects)].

УДК 374:7.022.82 (477.87)

DOI: 10.36550/2415-7988-2021-1-192-203-209
10. Khutorskoy, A. V. (2004). Praktikum po didaktike I sovremennym metodikam obucheniya. [Workshop on didactics and modern teaching methods]. Piter.

\section{ВІДОМОСТІ ПРО АВТОРА}

САРНОВСБКА Наталія Іванівна викладач кафедри іноземної філології Київського національного університету культури і мистецтв.

Наукові інтереси: сучасні освітні технології, викладання іноземних мов в закладах вищої освіти, міжкультурна комунікація, методика викладання іноземних мов.

АНТОНІВСЬКА Марина Олександрівна викладач кафедри іноземної філології Київського національного університету культури і мистецтв.

Наукові інтереси: методика викладання англійської мови у ЗВО, новітні парадигми, інтеркультурна комунікація, перекладознавчий аспект.

\section{INFOTMATION ABOUT THE AUTHOR}

SARNOVSKA Nataliia Ivanivna - Lecturer at the Foreign Philology Department, Kyiv National University of Culture and Arts.

Circle of scientific interests: Modern educational technologies, teaching foreign languages in higher educational institutions, intercultural communication, methodology of foreign languages teaching.

ANTONIVSKA Maryna Oleksandrivna Lecturer at the Foreign Philology Department, Kyiv National University of Culture and Arts.

Circle of scientific interests: methodology of English language teaching in higher educational establishments, the latest paradigms in English teaching, intercultural communication, translation aspects.

Стаття надійшла до редакиії 28.01.2021 p.

СОФІЛКАНИЧ Марина Іванівна -

аспірант Мукачівського державного університету, викладач Закарпатської академії мистецтв

ORCID: https://orcid.org/0000-0002-6793-4807

e-mail: marinasofilkanych82@gmail.com

\section{ЗАКЛАДИ ПОЗАШКІЛЬНОЇ ОСВІТИ ЗАКАРПАТТЯ В СИСТЕМІ БЕЗПЕРЕРВНОЇ ХУДОЖНЬОЇ ОСВІТИ}

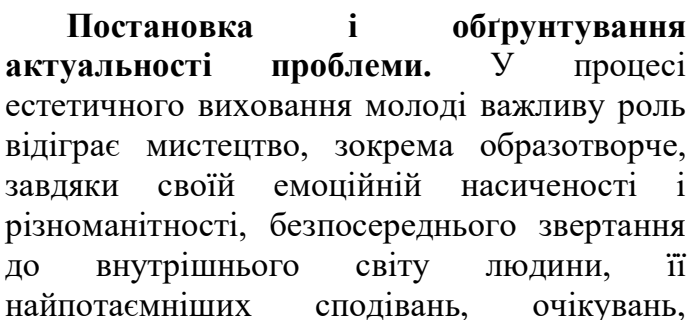

багатства проявів у суспільному житті.

Однією 3 основних баз поширення позашкільної художньо-естетичної культури $€$ дитячі школи мистецтв (ДШМ), які належить до початкових спеціалізованих мистецьких навчальних закладів. Заклади позашкільної освіти - складова системи позашкільної освіти, що надає знання, 